WHC-EP-0831

UC-2020

\title{
Preliminary Analysis of Tank 241-C-106 Dryout Due to Large Postulated Leak and Vaporization
}

\author{
M. G. Piepho
}

Date Published

December 1994

Prepared for the U.S. Department of Energy Office of Environmental Restoration and Waste Management
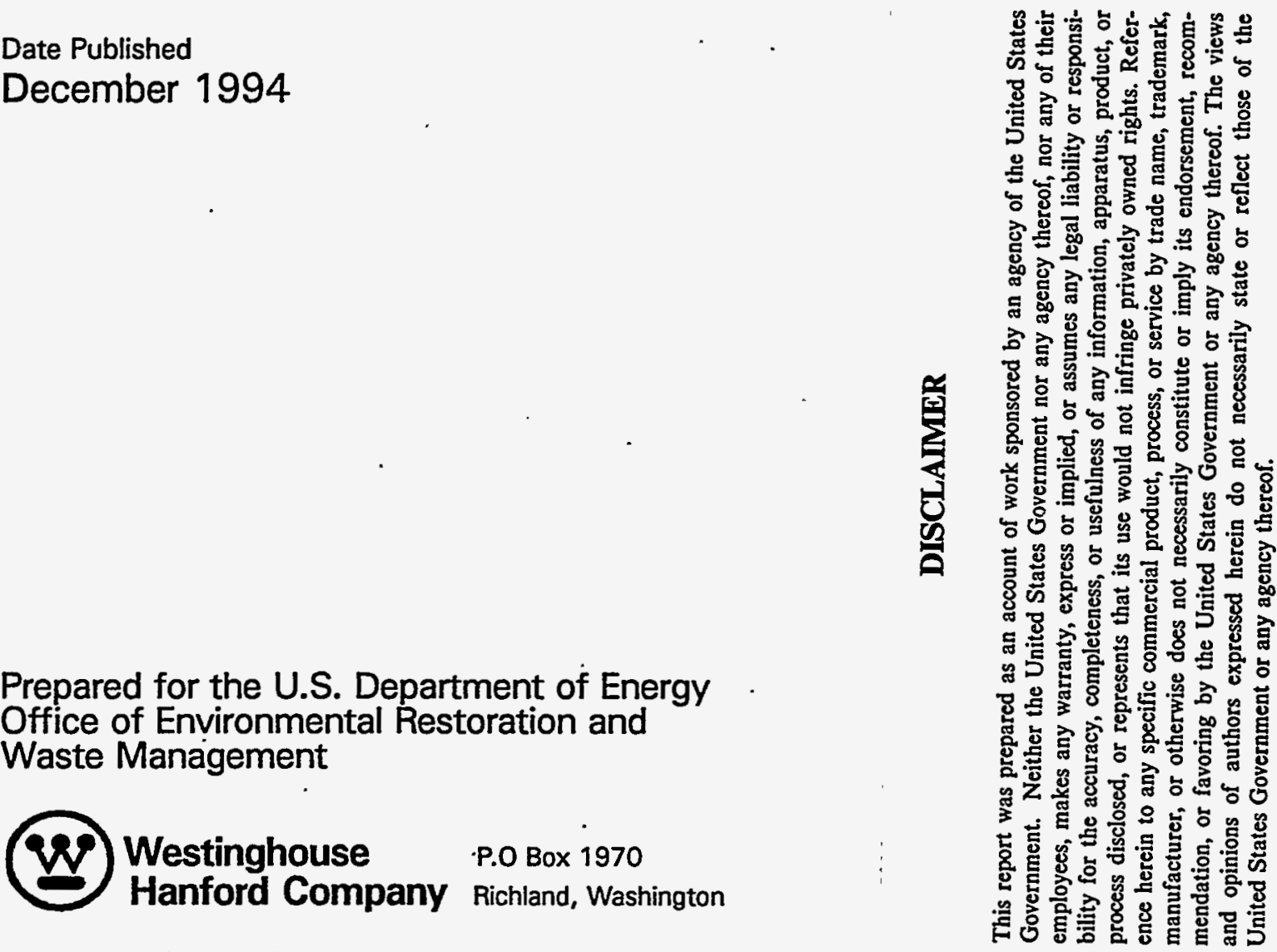

Henford Operations and Engineering Contractor for the U.S. Department of Energy under Contract DE-AC06-87RL10930 
WHC-EP-0831

LEGAL DISCLAIMER

This report was prepared as an account of work sponsored by an agency of the United States Government. Neither the

United States Government nor any agency thereof, nor any of their employees, nor any of their contractors, subcontractors or their employees, makes any warranty, express or implied,

or assumes any legal liability or responsibility for the accuracy, completeness, or any third party's use or the results of such use of any information, apparatus, product, or process disclosed, or represents that its use would not infringe privately owned rights. Reference herein to any specific commercial product, process, or service by trade name, tredemark, manufacturer, or otherwise, does not necessarily constitute or imply its endorsement, recommendation, or favoring by the United States Government or any agency there of or its contractors or subcontractors. The views and opinions of authors expressed herein do not necessarily state. or reflect those of the United States Government or any agency thereof.

This report has been reproduced from the best available copy. Aveilable in paper copy and microfiche.

Available to the U.S. Department of Energy and its contractors from

Office of Scientific and Technical Information

P.O. Box 62

Oak Ridge, TN 37831

(615) 576-8401

Available to the public from the U.S. Department of Commerce National Technical Information Service

5285 Port Royal Road

Springfield, VA 22161.

(703) $487-4650$

Printed in the United States of America

DISCLM-1.CHP (1-91) 


\section{DISCLAIMER}

Portions of this document may be illegible in electronic image products. Images are produced from the best available original document. 


\section{EXECUTIVE SUMMARY}

This analysis assumes that there is a hypothetical large leak at the bottom of Tank 241-C-106 which initiates the dryout of the tank. The time required for a tank to dryout after a leak is of interest for safety reasons. As a tank dries outs, its temperature is expected to increase which could affect the structural integrity of the concrete tank dome. Hence, it is of interest to know how fast and how high the temperature in a leaky tank increases, so that mitigation procedures can be planned and implemented in a timely manner.

This analysis focused on tank 241-C-106, which is known to be high thermal tank. The objective of the study was to determine how 7 ong it would take for tank 241-C-106 to reach 350 degrees Fahrenheit (about 177 degrees Centigrade) after a postulated large leak develops at the bottom center of the tank. The temperature of 350 degrees Fahrenheit is the minimum temperature that can cause structural damage to concrete (ACI 1992). The postulated leak at the bottom of the tank and the resulting dryout of the sludge in the tank make this analysis different from previous thermal analyses of the C-106 tank (Bander 1993) and other tanks, especially the double-shell tanks which are mostly liquid (Sathyanarayana et al. 1993).

This analysis is preliminary in the sense that actual data values (both hydrautic and thermal properties) for tank C-106 were not available. Hence, a range of data values were used in this analysis. In the worst-case scenario (backfill soil properties for sludge), it would take more than five months after the tank starts leaking before the maximum tank temperature-reaches 350 degrees Fahrenheit. Most 7ikely (the expected-case scenario), the maximum tank temperature reaches 350 degrees Fahrenheit after more than one year if a massive leak at the bottom center of tank were to occur.

One of the main recommendations for future analyses is that real data should be obtained from tank 241-C-106 or from a very similar tank. 
WHC-EP-0831

TABLE OF CONTENTS

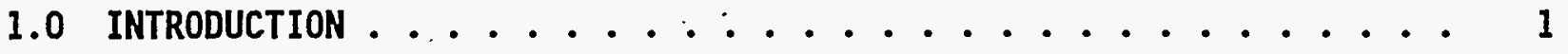

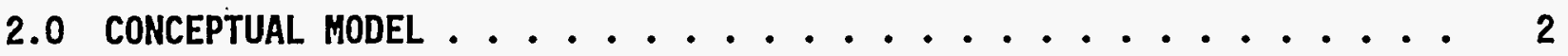

3.0 MATHEMATICAL/NUMERICAL MODEL ................. 4

4.0 HYDRAULIC AND THERMAL DATA .............. 5

4.1 HYDRAULIC DATA ................ 5

4.2 THERMAL DATA ..................... 6

5.0 RESULTS AND CONCLUSIONS .................... 8

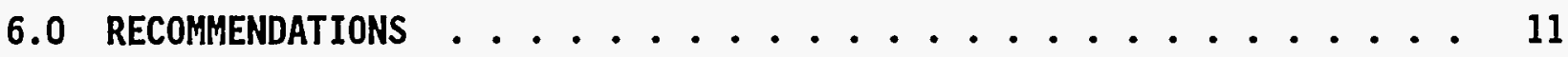

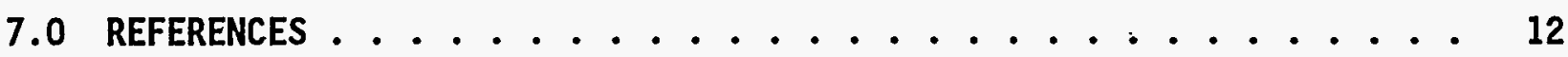

APPENDIX A TEMPERATURE AND SATURATION CONTOUR PLOTS . . . . . . A-1

APPENDIX B HEAT-PIPE PROBLEM FOR TOUGH2 BENCHMARK CASE . . . . . . B-1 


\section{WHC-EP-0831 \\ LIST OF TABLES/FIGURES}

\section{TABLES}

TABLE 4.1 Summary of Hydraulic Properties ............ 5

TABLE 4.2 Summary of Thermal Properties . . . . . . . . . 6

TABLE 5.1 Peak Maximum Temperatures and Time of Peak ........8 FIGURES

FIGURE 2.1 Conceptual Model for Tank Dryout Analysis . . . . . . . 3

FIGURE 5.1 Maximum Tank Temperatures . . . . . . . . . 9

FIGURE A.1 Tank Temperatures at 4 and 107 Days . . . . . . . A-3

FIGURE A.2 Tank Temperatures at 278 and 313 Days . . . . . . . . A-4

FIGURE A.3 Tank Temperatures at 339 and 365 Days . . . . . . . A-5

FIGURE A.4 Liquid Saturations at 4 and 107 Days . . . . . . . A-6

FIGURE A.5 Liquid Saturations at 278 and 313 Days . . . . . . . A-7

FIGURE A.6 Liquid Saturations at 339 and 365 Days . . . . . . . A-8 
WHC-EP-0831

\subsection{INTRODUCTION}

This analysis assumes that there is a hypothetical large leak at the bottom of Tank 241-C-106 which initiates the dryout of the tank. The time required for a tank to dryout after a leak is of interest for safety reasons. As a tank dries outs, its temperature is expected to increase which could affect the structural integrity of the concrete tank dome. Hence, it is of interest to know how fast the temperature in a Teaky tank increases, so that mitigation procedures can be planned and implemented in a timely manner.

This analysis focused on tank 241-C-106, which is known to be high thermal tank. The objective of the study was to determine how long it would take for tank 241-C-106 to reach 350 degrees Fahrenheit (about 177 degrees Centigrade) after a postulated large leak develops at the bottom center of the tank. The temperature of 350 degrees Fahrenheit is the minimum temperature that can cause structural damage to concrete (ACI 1992). The postulated leak at the bottom of the tank and the resulting dryout of the sludge in the tank make this analysis different from previous thermal analyses of the C-106 tank (Bander 1993) and other tanks, especially the double-shell tanks which are mostiy liquid (Sathyanarayana et a7. 1993).

The conceptual model for the tank dryout analysis is given in Section 2.0, and the mathematical/numerical model is briefly described in Section 3.0. The hydraulic and thermal data used in the analysis is presented in Section 4.0. All of the data have SI (MKS) units because these are the only units that the computer code would use, and SI units are now the standard at the Hanford site. The results from five bounding cases are reported in Section 5.0, with the summary and recommendations given in Section 6.0. 


\subsection{CONCEPTUAL MODEL}

The scenario used in this analysis is that a large hole (1-m in diameter) is postulated to open in the bottom center of the tank. This large hole is unrealistic, but it does provide a conservatively rapid loss of drainable 1iquid. Some of the fluid, which is assumed to be water, in the tank sludge then drains out of the large hole. into the soil below the hole. The ventilation system for the tank is assumed to be turned off when the leak starts.

The waste in the single-shell tanks at the Hanford Site can vary from a sludge to a salt cake. The sludge itself can vary from a fluid slurry to a hard paste. In this analysis of dryout of the tank, the sludge is represented by a porous medium. As fluid drains out from the tank, the sludge will clearly behave as a porous medium as the ratio of fluid volume to total volume becomes fairly low (less than 0.1). Unsaturated porous media have the common characteristic of holding onto some fluid due to capillary forces, and, hence, they do not let all of the fluid drain. The ability of a porous media to hold its fluid is a very important property which can vary greatly from one porous medium to another. For example, concrete tends to hold onto its water very tight7y, whereas gravel tends to have almost no water-retention capability. Sand and backfill-soil water-retention properties are somewhere in between concrete and gravel.

The conceptual model assumes azimuthal symmetry (radius and height are the only spatial variables) and is shown graphically in Figure 2.1. This 3D (the code assumes a full circle) analysis, with azimuthal symmetry (i.e., cylindrical coordinates with no angle dependence), assumes two types of porous media for the sludge in Tank 241-C-106: 1) a backfill soil that is fairly permeable and represents a worst-case choice of medium, and 2) the Ringold geologic formation (a basalt layer), which is somewhat impermeable and exists in the soil stratigraphy at the Hanford Site.

These two media are hydraulically well characterized (Piepho 1994). The Ringold formation is expected to provide the best-estimate hydraulic properties for the true sludge, and the backfill soil, which is very porous like sand, is expected to provide the worst-case hydraulic properties for the true sludge. Two types of porous media were used since the hydrautic properties of the specific sludge in tank 241-C-106 have not been characterized yet. No consideration was given to possible cracks in the sludge and between the sludge and tank in this preliminary analysis. Also, no fumaroles in the sTüdge were considered. "Cracks and fumaroles will be considered in future analyses. 
WHC-EP-0831

FIGURE 2.1 Conceptual Model

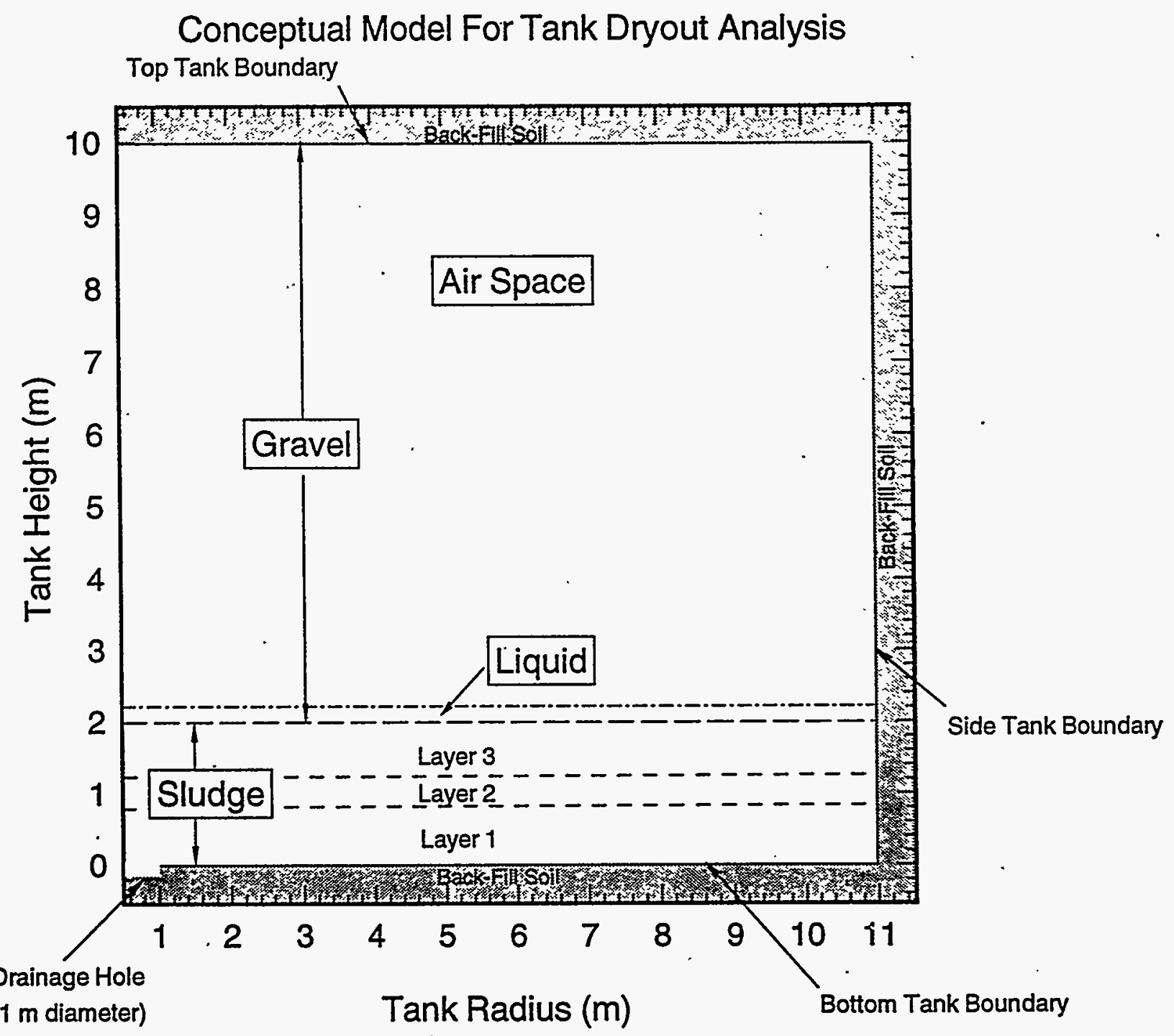


Since the air space above the sludge in the tank is important for holding. vapor emitted from the hot sludge, it was included in the model as a largeporosity $(99 \%)$ gravel. The porous-media computer code that was used for the analysis, needs porous-media properties for all spatial regions of the model even if the spatial region is an air space. Gravel properties will permit high velocities to take place and moisture retention capability is almost nonexistent; hence, the gravel hydraulic properties are closer to pure air properties than those of other porous media. The large porosity of 0.99 essentially makes this gravel all air anyway.

Backfill soil properties were used for the boundaries below and above the tank and on the side of the tank as shown in Figure 2.1, except that a zero hydraulic conductivity was assumed to represent the impermeable tank shell, creating a no-flow situation.

Five cases with different thermal conductivities and specific heats for the sludge were simulated in this analysis (see Section 4.0 for the details).

\subsection{MATHEMATICAL/NUMERICAL MODEL}

The mathematical model consists of the mass and energy-balance equations required for nonisothermal multiphase flow (Pruess 1991). Darcy's Law is assumed for the hydraulic pressure of 1 iquid water and gas. These equations are solved numerical7y by the TOUGH2 (Transport of Unsaturated Groundwater and Heat) code (Preuss 1991). The primary multi-phase thermodynamic variables are gas (both air and vapor) pressure, gas saturation, and temperature. The gas saturation is the fraction of the porous-medium pore space that is filled with air and vapor; the other fraction is filled with liquid and is called the liquid saturation.

The fourth equation-of-state (EOS4) module was chosen from the TOUGH2 suite of modules. TOUGH2 includes various equation-of-state systems for various gasliquid systems such as water-hydrogen, water-carbon-dioxide, water-air, etc. The EOS4 module provides the equations of state for a water-air system with vapor pressure-lowering effects (Pruess 1991). The vapor pressure-lowering effects are a result of very dry conditions. For very dry conditions, the vapor pressure is lower than what the ideal gas law would predict; hence, the vapor pressure calculation is modified in EOS4, according to Kelvin's equation, to be lower than the ideal gas law's prediction. This is known as the vapor pressure-lowering effect.

The TOUGH2. code is one of the few codes chosen for modeling unsaturated water flow and heat for the proposed DOE HLW repository site at Yucca Mountain, Nevada. As part of the Yucca Mountain Project Quality Assurance, the TOUGH code has gone through much scrutiny, review and testing (Mangold 1993). 
WHC-EP-0831

\subsection{HYDRAULIC AND THERMAL DATA}

The analysis for the tank dryout was very difficult because of the coupled processes of unsaturated water flow and heat. When each process is modeled separately, the analysis is much simpler, but when the processes are coupled, the analysis gets about a hundred times harder. The hydraulic data is presented in Section 4.1 and the thermal data is presented in Section 4.2. This analysis is preliminary in the sense that most of the data used in this analysis was not obtained from measuring sludge, but rather from other sources.

\subsection{HYDRAULIC DATA}

The measured hydraulic data for the Grout Disposal Facility at Hanford (Piepho 1994) was used for all of the porous media types used in this analysis.

However, some changes were made to the original data to get closer to the tank conditions. For example, the porosity (the fraction of pore space in the medium) of the gravel was increased to 0.99 so that it better represented an air space above the sludge in the tank. Also, the permeability of the gravel and the Ringold formation were both increased by a factor of ten to make them both more permeable to fluid flow on order to better approximate the air space and sludge, respectively. The hydraulic data used in this analysis is

presented in Table 4.1. The best information on sludge permeability was found in Handy's (1975) report, which estimated generic sludge to have a permeability of about 0.01 Darcy (10 mil1i-Darcy).

TABLE 4.1 Summary of Hydraulic Properties

\begin{tabular}{|c|c|c|c|c|c|}
\hline Material & $\begin{array}{c}\text { Permeabi1 ity } \\
\text { (Darcy) }\end{array}$ & Porosity & $\begin{array}{c}\text { Residual } \\
\text { Moisture }\end{array}$ & $\begin{array}{c}\text { Alpha } \\
(1 / \mathrm{m})\end{array}$ & $\mathbf{n}$ \\
\hline $\begin{array}{c}\text { Air Space } \\
\text { (Grave1) }\end{array}$ & 18500 & 0.99 & 0.014 & 353.66 & 2.661 \\
\hline $\begin{array}{c}\text { Sludge } \\
\text { (Backfi17 Soi1) }\end{array}$ & 30 & 0.37 & 0.045 & 6.83 & 2.08 \\
\hline $\begin{array}{c}\text { Sludge } \\
\text { (RingoTd) }\end{array}$ & 0.0242 & 0.50 & 0.0283 & 1.76 & 1.338 \\
\hline
\end{tabular}

The van Genuchten-Mualem relationships (van Genuchten 1978, Mualem 1976), which are defined by the parameters alpha and $n$ (see Table 4.0), were used for the moisture-retention and relative permeability characteristic curves.

The backfill-soil properties were used for the boundary cells for all cases and for the sludge for two cases. The Ringold formation properties were used for the sludge for three cases. 


\subsection{THERMAL DATA}

Most of the thermal data came from Bander (1993) and Bouse (1975). The key thermal data includes the heat generation rate per unit volume, the thermal conductivity for both fully wet and completely dry media, and the specific heat for the solid material. All of the thermal properties for water and water vapor are contained in the EOS4 module of the TOUGH2 code. The therma1 parameters used in the code are presented in Table 4.2.

\section{TABLE 4.2 Summary of Thermal Properties}

\begin{tabular}{|c|c|c|c|c|}
\hline Material & $\begin{array}{l}\text { Heat } \\
\text { Generation } \\
\left(W / \mathrm{m}^{3}\right)\end{array}$ & $\begin{array}{c}\text { Wet Thermal } \\
\text { Conductivity } \\
(W / \mathrm{m}-\mathrm{C})\end{array}$ & $\begin{array}{c}\text { aDry Thermal } \\
\text { Conductivity } \\
(\mathrm{W} / \mathrm{m}-\mathrm{C})\end{array}$ & $\begin{array}{c}\text { Specific } \\
\text { Heat of } \\
\text { Sol id } \\
(\mathrm{J} / \mathrm{kg}-\mathrm{C})\end{array}$ \\
\hline $\begin{array}{c}\text { Air Space } \\
\text { (Grave1) }\end{array}$ & 0 & $\begin{array}{c}0.6 \\
\text { (99\% water) }\end{array}$ & $\begin{array}{c}0.027 \\
(99 \% \text { air })\end{array}$ & $\begin{array}{c}800 \\
(1 \% \quad \text { s.07id) }\end{array}$ \\
\hline $\begin{array}{c}\text { S7udge Bottom } \\
\text { Layer 1 } \\
\text { (Ringold \& BF soil) }\end{array}$ & 52.2 & 0.80 & 0.16 & 800 \\
\hline $\begin{array}{c}\text { Sludge Middle } \\
\text { Layer } 2 \\
\text { (Ringold \& BF Soil) }\end{array}$ & 68.7 & 0.80 & 0.16 & 800 \\
\hline $\begin{array}{c}\text { STudge Top } \\
\text { Layer } 3 \\
\text { (Ringold \& BF SoiT) } \\
\end{array}$ & 17.2 & 0.80 & 0.16 & 800 \\
\hline \multicolumn{5}{|l|}{ Sensitivity Cases: } \\
\hline $\begin{array}{c}\text { Sludge with } \\
\text { Medium Conductivity } \\
\text { (Ringold) }\end{array}$ & & 1.3 & & \\
\hline $\begin{array}{c}\text { Sludge with } \\
\text { High Conductivity } \\
\text { (Ringold) }\end{array}$ & & 1.7 & & \\
\hline $\begin{array}{c}\text { Sludge with } \\
\text { High Specific Heat } \\
\text { (BF soil) }\end{array}$ & & & & 1200 \\
\hline
\end{tabular}

a) The dry thermat conductivities were not used in the simulations shown in this report; ' use of the dry conductivities would cause higher temperatures under dryout conditions and will be used in future anlyses.

The heat generation rates correspond to a total heat load of 110,000 BTUs per hour $(32,240$ Watts $)$. The spatial heat generation distribution, which is 
highest in the middle sludge layer and lowest in the top sludge layer, was, determined by Bander (1993).

The thermal conductivities came from Bouse (1975) as he performed real measurements on both wet and dry s7udge. The thermal conductivity of ful7ywet gravel (99\% water) representing the tank air space is basically that of water, and the thermal conductivity of dry gravel (99\% air) is that of air. However, the dry thermal conductivities were not used in these analyses, but will be used in future analyses. When water is present, much of the heat is transferred by convection (both 7 iquid and vapor); hence, the dry thermal conductivities wi11 have their most importance when parts of the sludge become dry. The dry thermal conductivities are listed in Table 4.2 so that the higher wet thermal conductivities can be contrasted to them.

The temperature initial.conditions were taken from Bander (1993) and are based on actual measured values taken around November 1991, a few months before the ventilation was temporarily turned off. 
WHC-EP-0831

\subsection{RESULTS AND CONCLUSIONS}

Five simulated cases are reported here. Many more cases were run, but the results from these five cases are considered to summarize and bound the analysis. The Ringold formation properties were used for the sludge properties for three cases with the thermal conductivity of $0.8,1.3$, and 1.7 $W / m-C$, respectively. As expected, the lowest value of thermal conductivity gave the most conservative results. The backfill soil properties were used for sludge properties for the two other cases with the specific heat for the solid being $800 \mathrm{~J} / \mathrm{kg}-\mathrm{C}$ and $1200 \mathrm{~J} / \mathrm{kg}-\mathrm{C}$, respectively. As expected, the smaller specific heat produced the more conservative results. The peak maximum temperatures, up to 177 degrees C, over the first year are tabulated in Tab7e 5.1. The maximum temperature in the tank for all times, up to one year, is shown graphically for each case in Figure 5.1.

TABLE 5.1 Peak Maximum Temperatures and Time of Peak

\begin{tabular}{|c|c|c|c|}
\hline Case No. & Case Description & Peak Maximum Temp. & Time of Peak \\
\hline 1 & $\begin{array}{c}\text { Sludge as Ringold, } \\
\text { Low Therm. Conduct. }\end{array}$ & $\begin{array}{c}177 \mathrm{deg} \text { C } \\
(350 \mathrm{deg} \text { F })\end{array}$ & $1 \mathrm{yr}$ \\
\hline 2 & $\begin{array}{c}\text { Sludge as Ringold, } \\
\text { Medium Therm. Conduct. }\end{array}$ & $\begin{array}{c}144 \mathrm{deg} \mathrm{C} \\
(290 \mathrm{deg} \text { F })\end{array}$ & $1 \mathrm{yr}$ \\
\hline 3 & $\begin{array}{c}\text { Sludge as Ringold, } \\
\text { High Therm. Conduct. }\end{array}$ & $\begin{array}{c}128 \mathrm{deg} \mathrm{C} \\
(263 \mathrm{deg} \text { F })\end{array}$ & $1 \mathrm{yr}$ \\
\hline 4 & $\begin{array}{c}\text { Sludge as BF Soi1, } \\
\text { Low Therm. Conduct. }\end{array}$ & $\begin{array}{c}177 \mathrm{deg} \mathrm{C} \\
(350 \mathrm{deg} \text { F })\end{array}$ & 165 days \\
\hline 5 & $\begin{array}{c}\text { Sludge as BF Soi1; } \\
\text { Low Therm. Conduct., } \\
\text { High Heat Capacity }\end{array}$ & $\begin{array}{c}177 \mathrm{deg} \mathrm{C} \\
(350 \mathrm{deg} \text { F })\end{array}$ & 190 days \\
\hline
\end{tabular}

The worst-case scenario (Case \# 4 with backfill soil properties for sludge), shows that it would take more than five months after the tank starts leaking before the maximum tank temperature reaches 350 degrees Fahrenheit. The sludge is not expected to be as porous or permeable as backfill soil. The sludge is expected to be closer to the Ringold formation which is more impermeable than backfill soil. With Ringold formation properties and conservative low thermal conductivity values, the maximum tank temperature reaches 350 degrees Fahrenheit at one year. With higher thermal conductivities, the heat is more easily conducted out of the tank, and the time to reach 350 degrees is greater than a year. 


\section{WHC-EP-0831}

FIGURE 5.1 Maximum Tank Temperatures for the Five Simulated Cases.

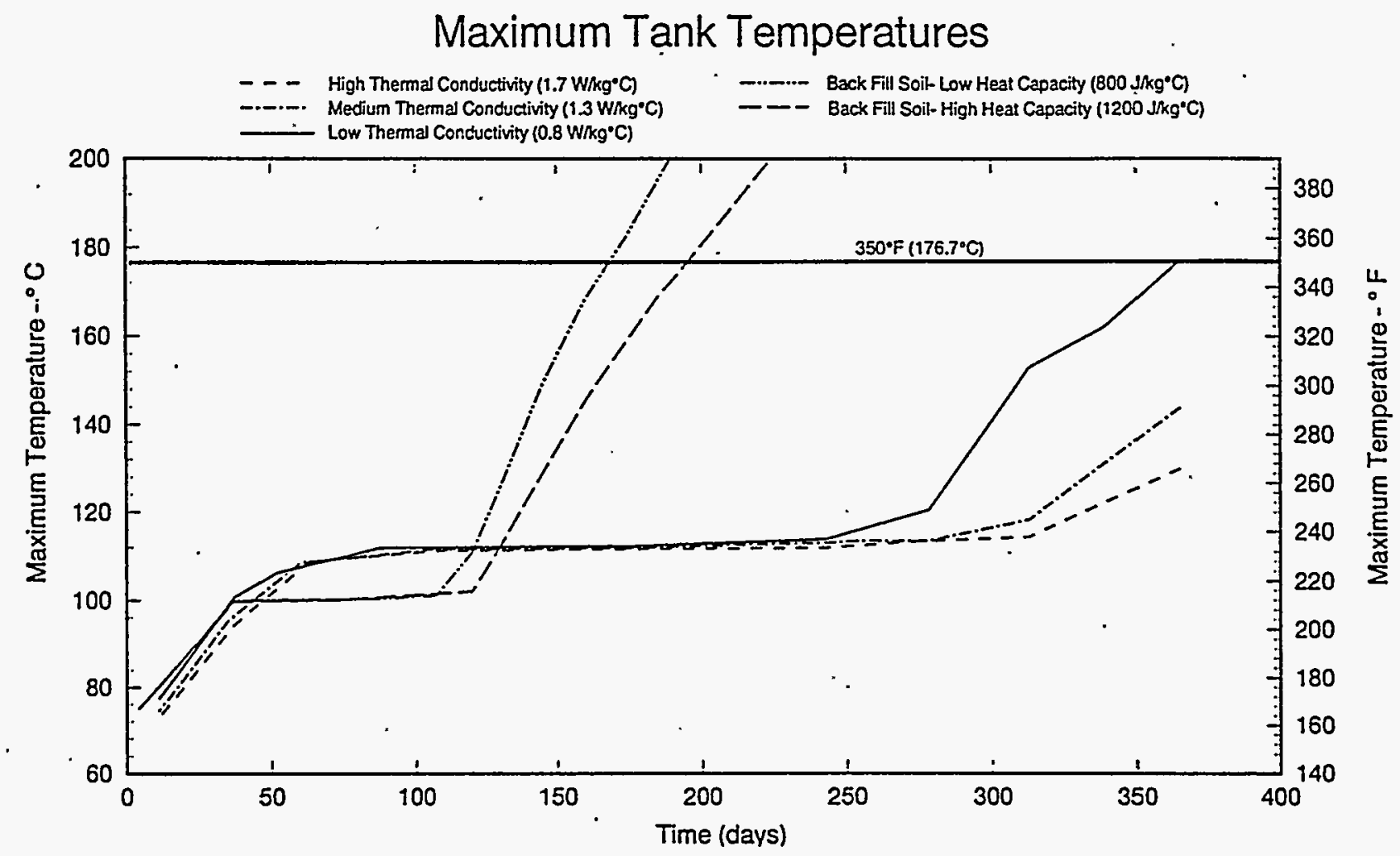


WHC-EP-0831

\subsection{RECOMMENDATIONS}

Since this analysis was preliminary, several improvements can be recommended. Obtaining specific hydraulic and thermal data for the sludge in Tank 241-C-106 or a very similar tank would certainfy be more reliable than assuming the values. Sludge properties can vary widely from tank to tank. Also, the s7udge properties may have a spatial distribution of hydraulic properties with the bottom sludge being more impermeable than the top sludge.

The most important sludge properties include the following: 1) permeability, 2) porosity, 3) moisture-retention relationship, 4) thermal conductivities, 5) specific heat, and 6) heat generation rate. Dry thermal conductivities were not used in this report, as they are not expected to be real important. However, since dry thermal conductivities are smaller than wet thermal conductivities, they will cause higher temperatures under dry conditions, and should be included in future analyses as they do have some importance. Under wet conditions, the dominant mode of heat transfer is convection (both fluid and vapor) and vaporization.

In addition to tank-specific data, the numerical grid could be improved: More soil elements need to be added around the tank so that the heat transfer to the soil is more accurate. Also, a concrete liner should be added between the soil and the sludge, so that the impermeable barrier is modeled more explicitly. Zero hydraulic conductivity was assigned to the soil boundary elements to stop the flow of water everywhere except where the leak was assigned, which was in the tank center.

No cracks were assumed in the sludge or between the sludge and the inner tank wal1. In the future, the effect of cracks should be studied and, perhaps, the effects of fumaroles. Also, air ventilation through the air space in the tank should be included in future analyses as well as the effects of an air chiller and the addition of water by spraying. The size and location of the leak also needs to be explored in future analyses.

The main recommended items to be included in future work is summarized below:

1) Dry thermal conductivities,

2) Cracks and fumaroles,

3) Air ventilation and air chiller,

4) Water sprays,

5) Better numerical grid,

6) Size and location of leak,

7) Better thermal/hydraulic data of tank, and

8) Diffusion of vapor. 
WHC-EP-0831

\subsection{REFERENCES}

ACI, 1992. ACI Manual of Concrete Practice: Part 4-1992, Appendix A, ANSI/ACI 349-85, pp. 79-80, American Concrete Institute, Detroit, Michigan.

Bander, T. J., 1993. Revised Thermal History of Tank 241-C-106, WHC-SD-WM-ER200, Rev. 0, Westinghouse Hanford Company, Richland, Washington.

Bouse, D. G., 1975. Thermal Conductivity of Hanford Waste Tank Solids and SX Farm Soil Samples, ARH-CD-378, Atlantic Richfield Company, Richiand, Washington.

Handy, L. L., 1975. Flow Properties of Salt Cake for Interstitial Liquid Removal/Immobilization Development Program, ARH-C-6, Atlantic Richfield Company, Richland, Washington.

Mangold, D., 1993. Qualifying Codes Under Software Quality Assurance: Two Examples as Guidelines for Codes that are Existing or under Develapment, LBL34423, Lawrence Berkeley Laboratory, Berkeley, California.

Mualam, Y., 1976; A New Model for Predicting the Hydraulic Conductivity of Unsaturated Porous Media, Water Resources Research, Vol 12 (3), 513-522. Company, Richtand, Washington.

Piepho, M. G., 1994. Grout Performance Assessment Results of Benchmark. Base. Sensitivity and Degradation Cases, WHC-SD-WM-TI-561, Rev. 0, Westinghouse Hanford Company, Richland, Washington.

Preuss, K., 1991. TOUGH2: A General-Purpose Numerical Simulator for Multiphase Fluid and Heat Flow, LBL-29400, Lawrence Berkeley Laboratory, Berkeley, California.

Sathyanarayana, K., M. J. Thurgood, and B. C. Fryer, 1993. Development of a Dynamic Computer Simulator for Aging Waste Tank Operations and Safety Assessment, WHC-SD-WM-ER-198, Westinghouse Hanford Company, Richland, Washington.

van Genuchten, M. Th., 1978; Calculating the Unsaturated Hydraulic Conductivity with a New Closed-Form Analytic Model, Report 78-WR-08, Water Resources Program, Dept. of Civil Engineering, Princeton University, Princeton, New Jersey. 
WHC-EP-0831

APPENDIX A

TEMPERATURE AND SATURATION CONTOUR PLOTS

A-1 


\section{A.1 Temperature and Saturation Results}

The temperature contours for the low-thermal-conductivity case with Ringoldformation properties are shown in Figures A.1 through A.3 for various times ranging from 4 days to 365 days. These plots show that the hot spot develops at the bottom of the tank between 7 and 9 meters from the center of the tank.

The liquid saturation (fraction of pore space that is liquid) contours for the same case are shown in Figures A.4 to A.6 for various times ranging from 4 days to 365 days. Figure A.4 shows that the sludge is still $49 \%$ saturated 107 days after the leak. This liquid is still present due to the capillary forces of the porous medium, but is leaving the medium due to the heat load causing evaporation. Condensation effects can be seen at the top and sides of the tank where the saturation is higher. The inner sludge is basically dried out 278 days after the leak as shown in Figure A.5, and the bottom sludge is very dry at 313 days. The upper sludge is starting to get very dry one year after the leak as shown in Figure A.6. Figures A.5 and A.6 show some water from the backfill soil boundary entering the tank at the leak location (bottom center), due to the strong capillary forces sucking the water into the tank. 
WHC-EP-0831

FIGURE A.1 Tank Temperatures at 4 and 107 Days

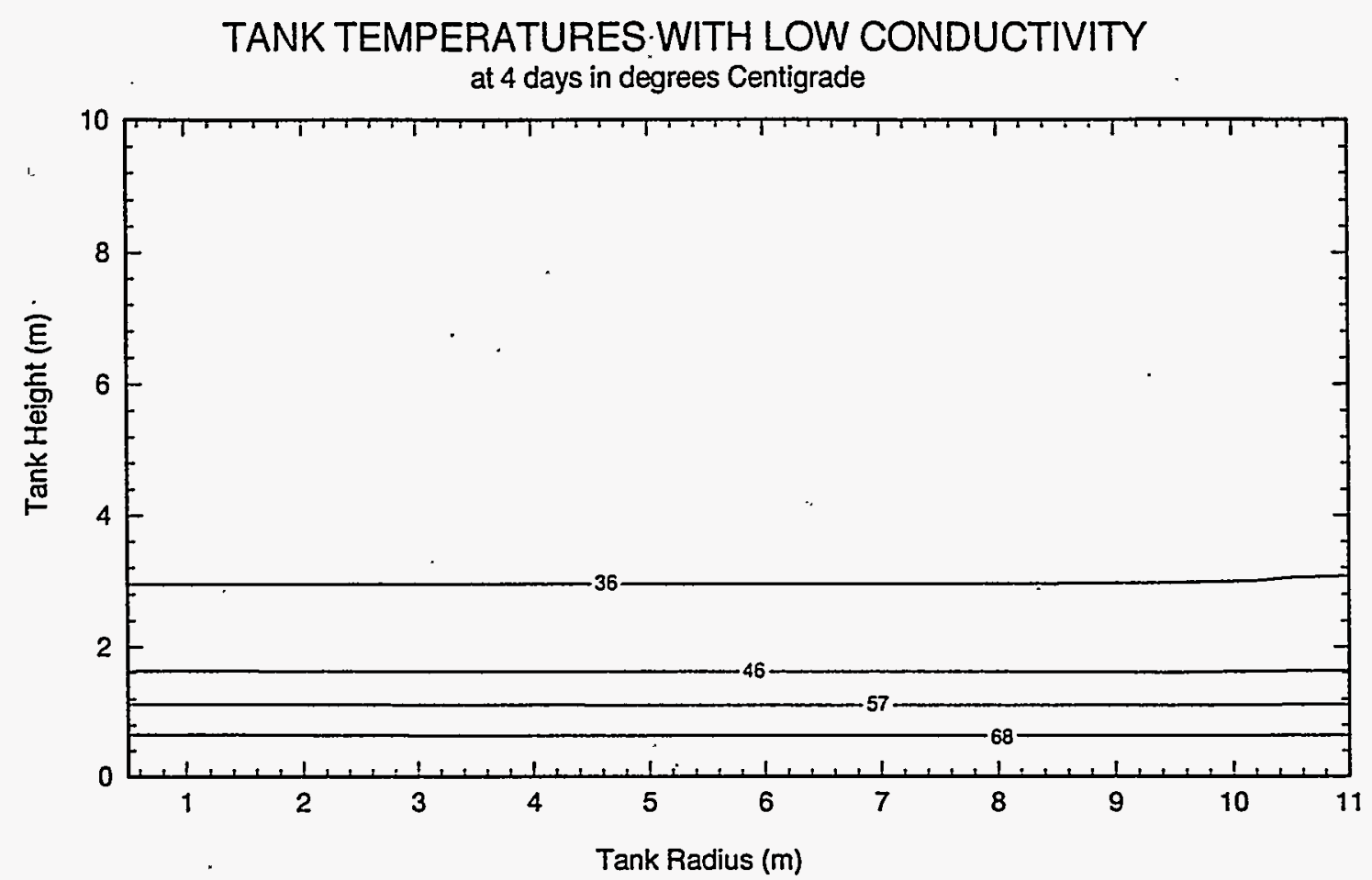

TANK TEMPERATURES WITH LOW CONDUCTIVITY at 107 days in degrees Centigrade

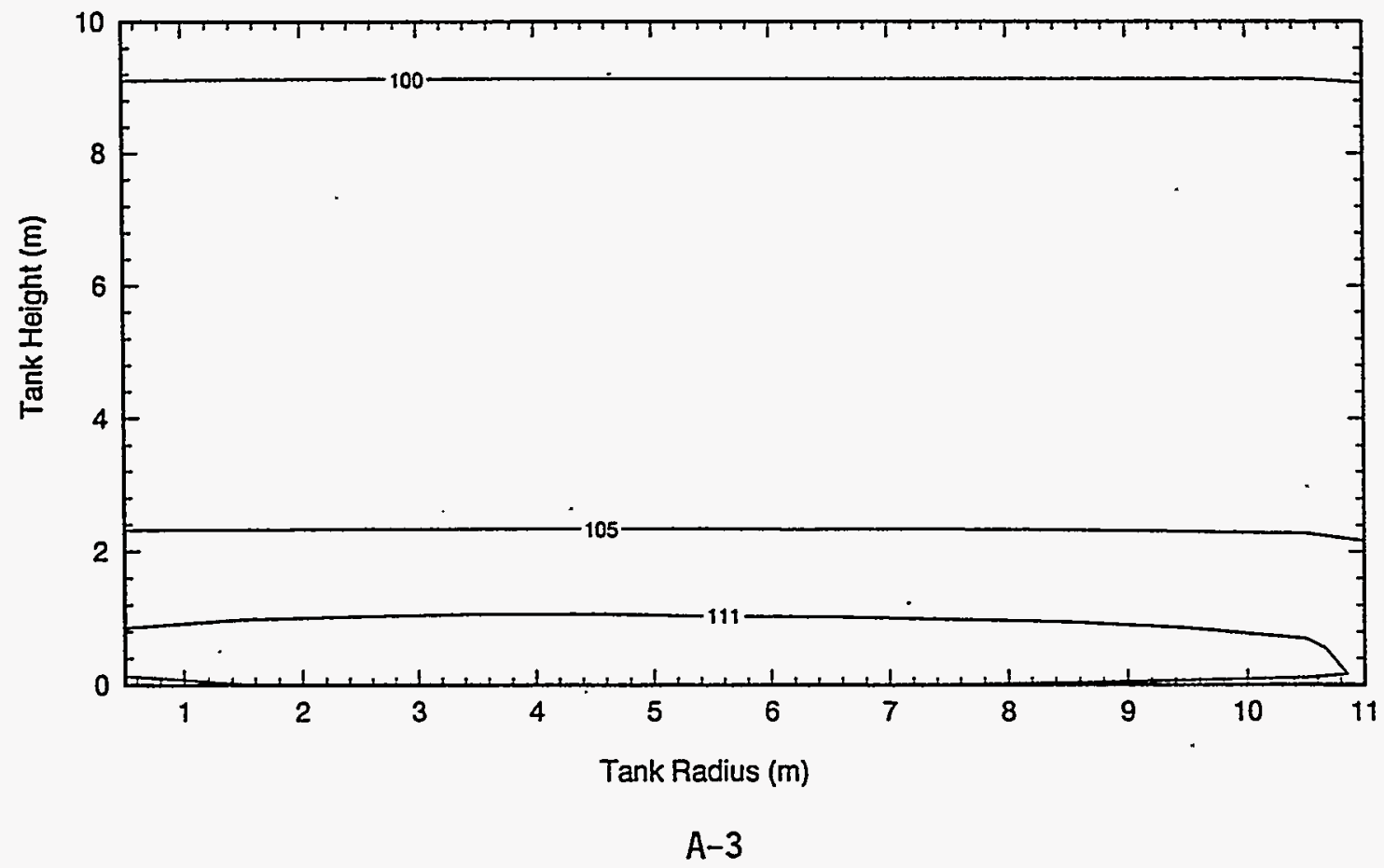


WHC-EP-0831

FIGURE A.2 Tank Temperatures at 278 and 313 Days
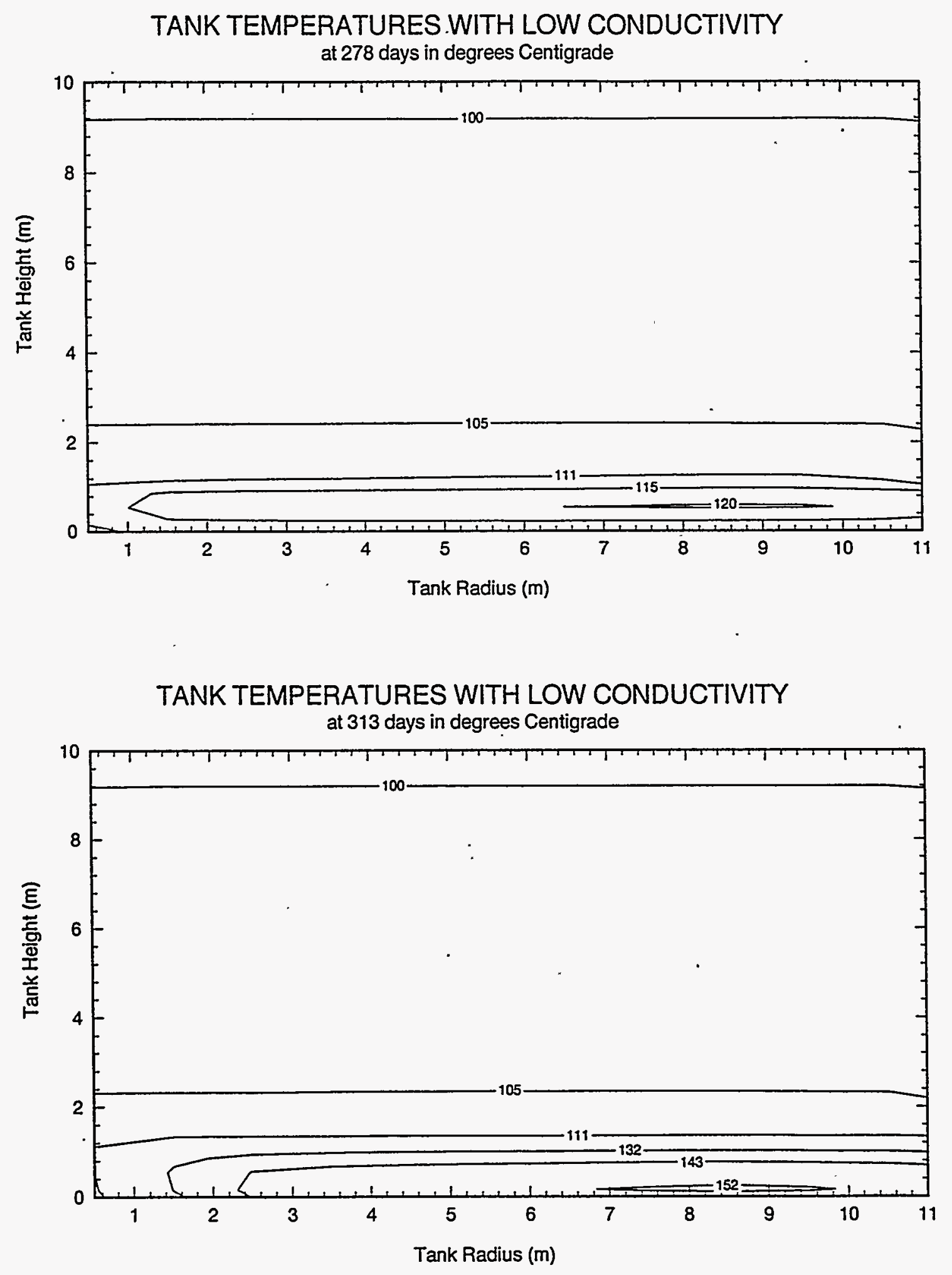

A-4 
WHC-EP-0831

FIGURE A.3 Tank Temperatures at 339 and 365 Days

TANK TEMPERATURES. WITH LOW CONDUCTIVITY at 339 days in degrees Centigrade

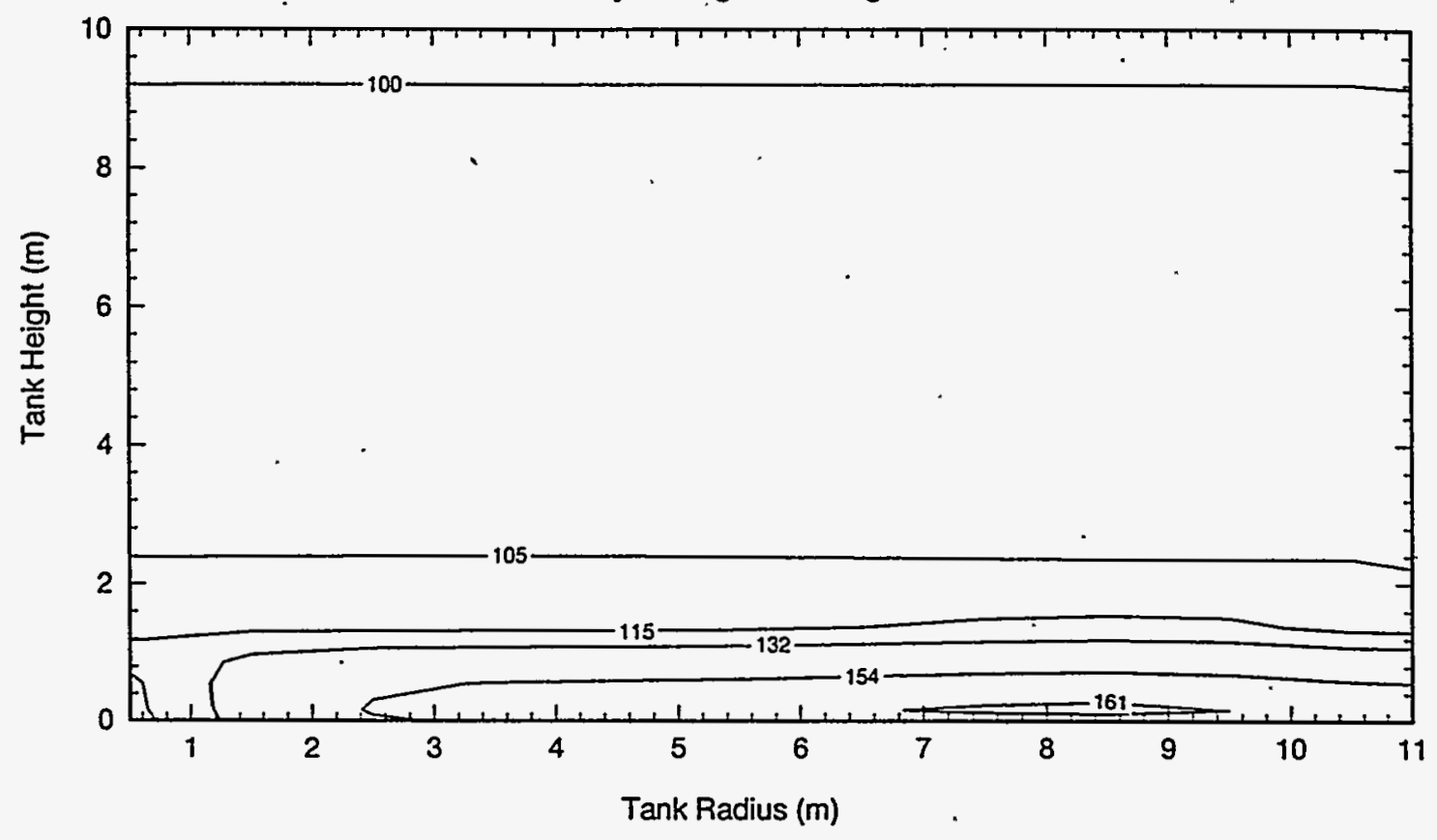

TANK TEMPERATURES WITH LOW CONDUCTIVITY at 365 days in degrees Centigrade.

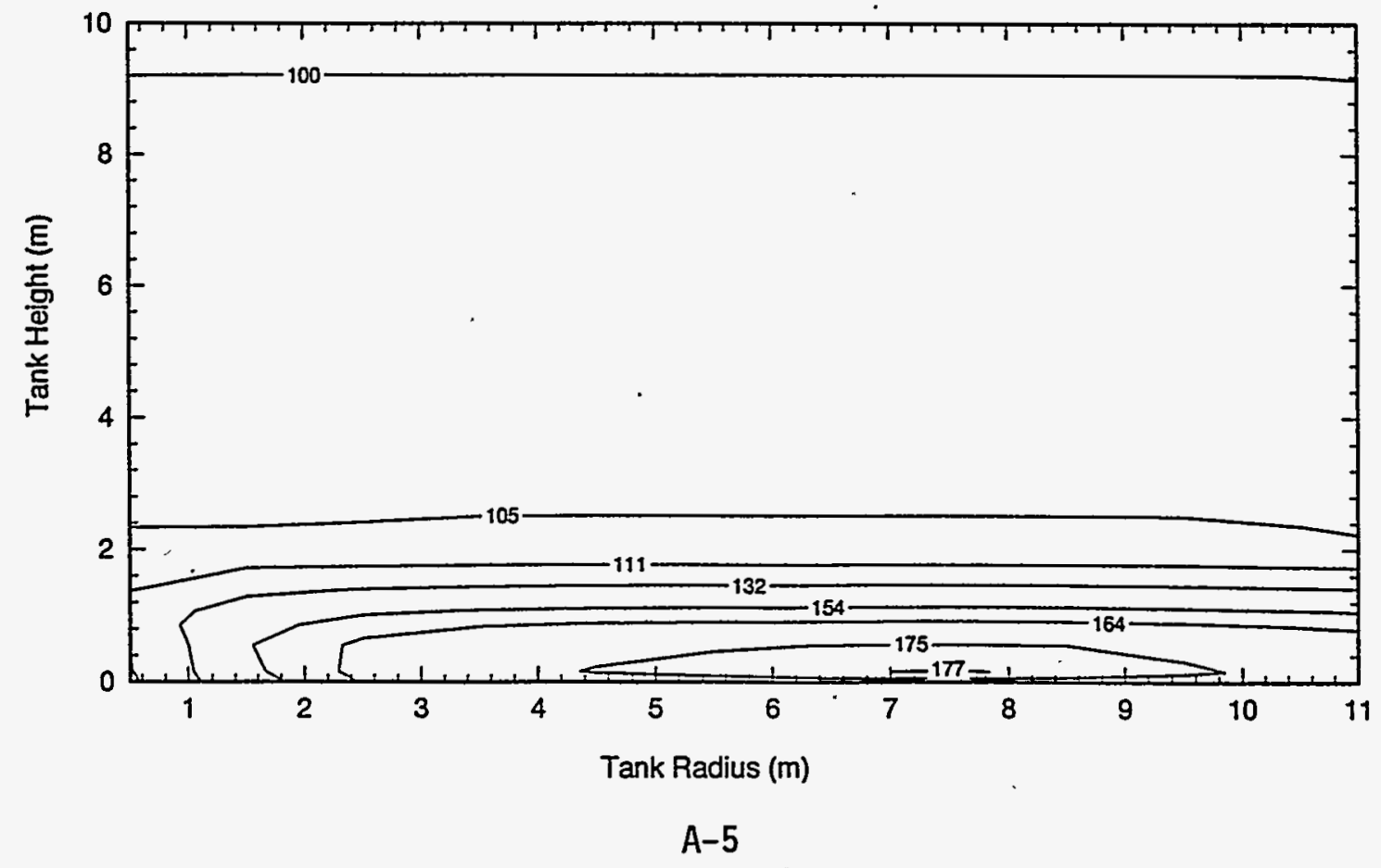


WHC-EP-0831

FIGURE A.4 Liquid Saturations at 4 and 107 Days

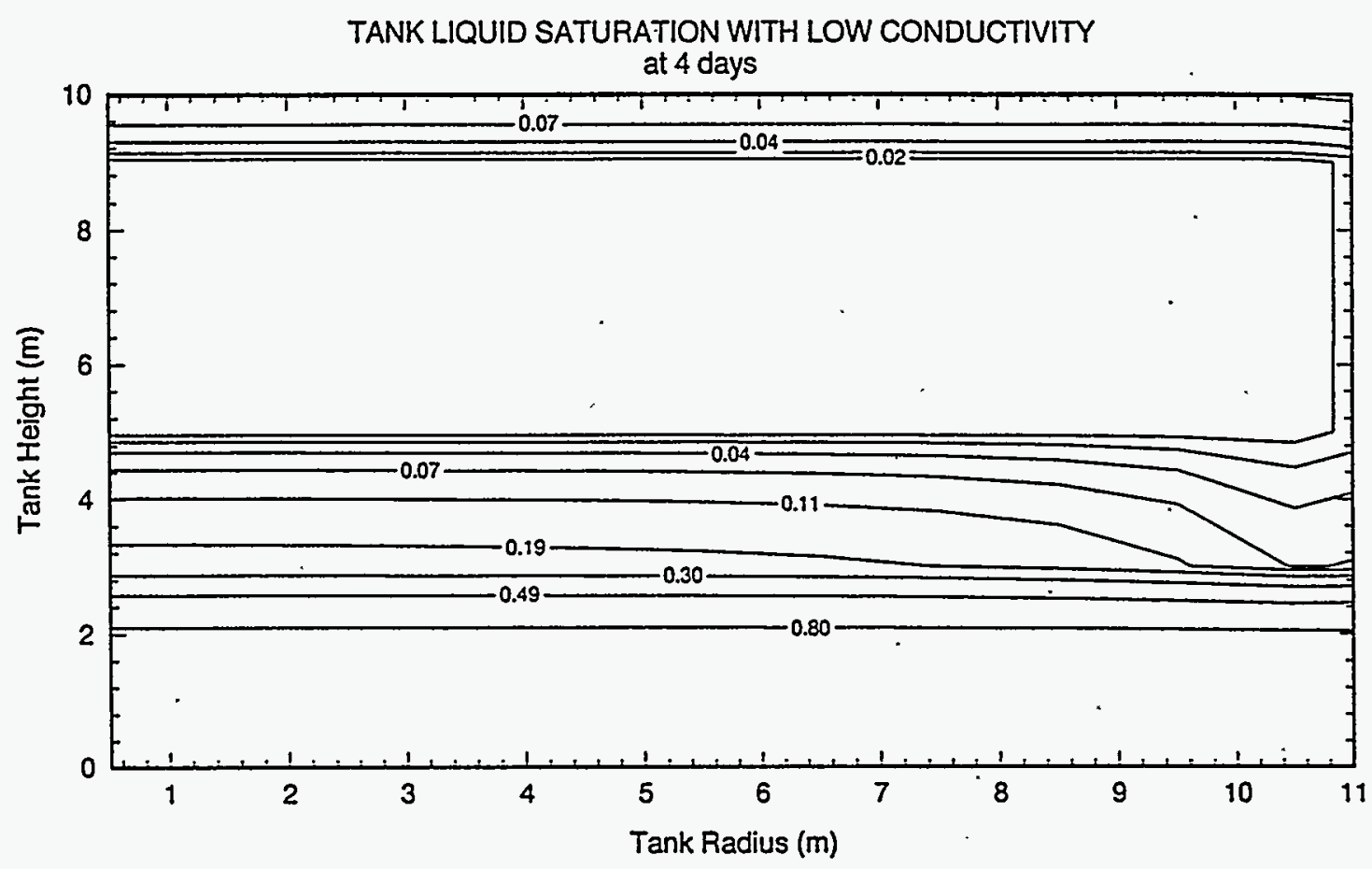

TANK LIQUID SATURATION WITH LOW CONDUCTIVITY at 107 days

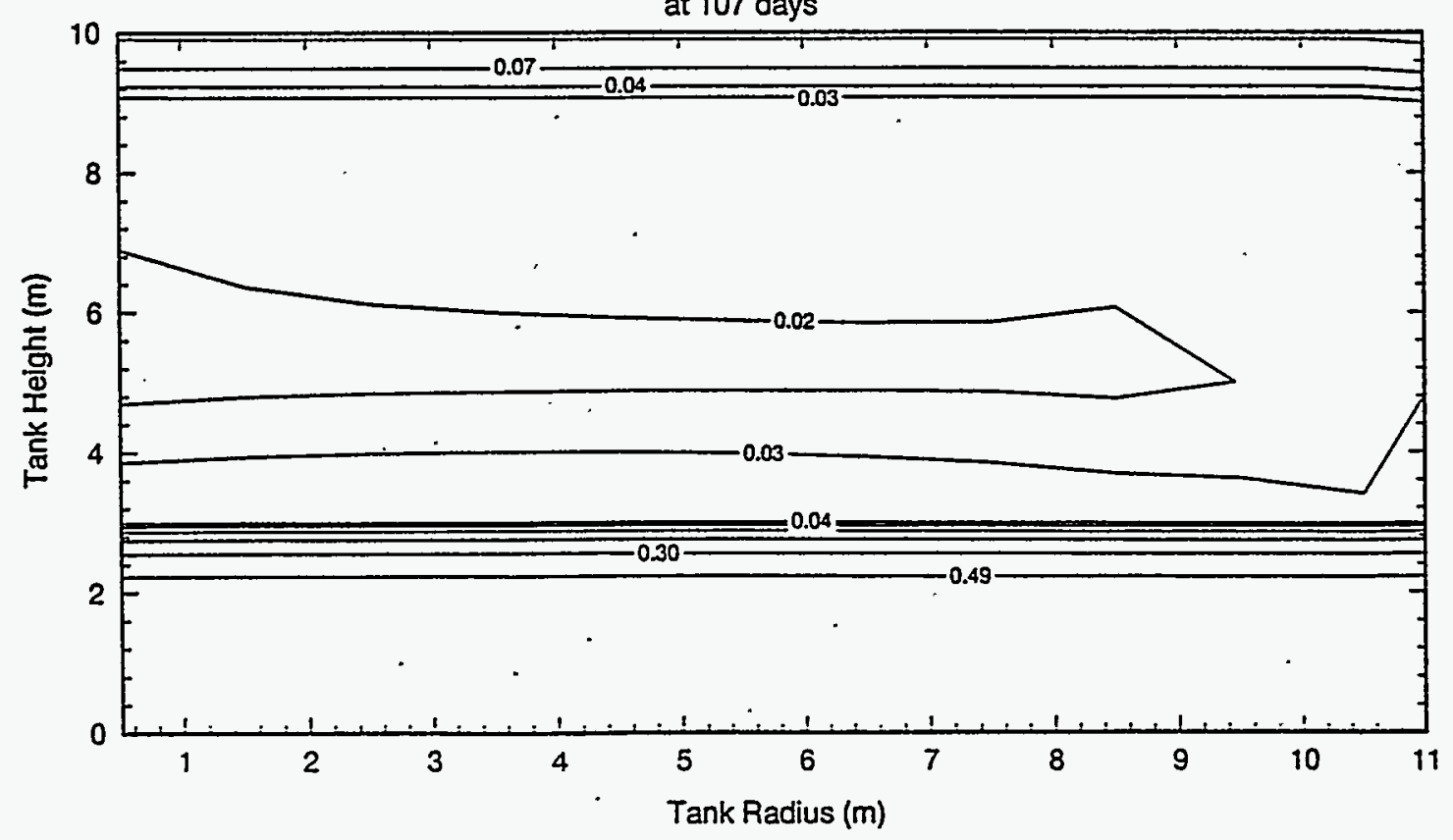

A-6 
WHC-EP-0831

FIGURE A.5 Liquid Saturations at 278 and 313 Days
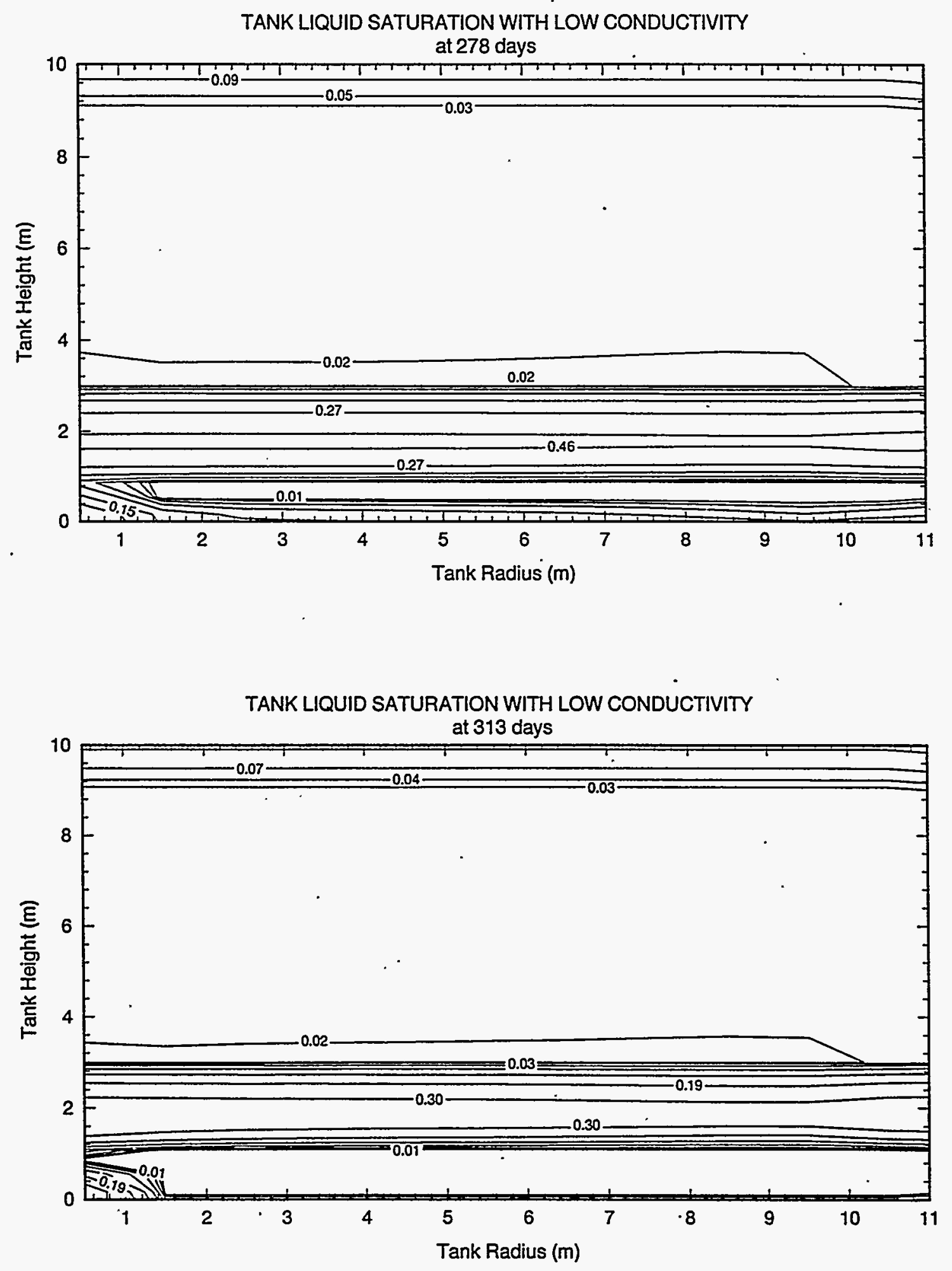

A-7 


\section{WHC-EP-0831}

\section{FIGURE A.6 ' Liquid Saturations at 339 and 365 Days}
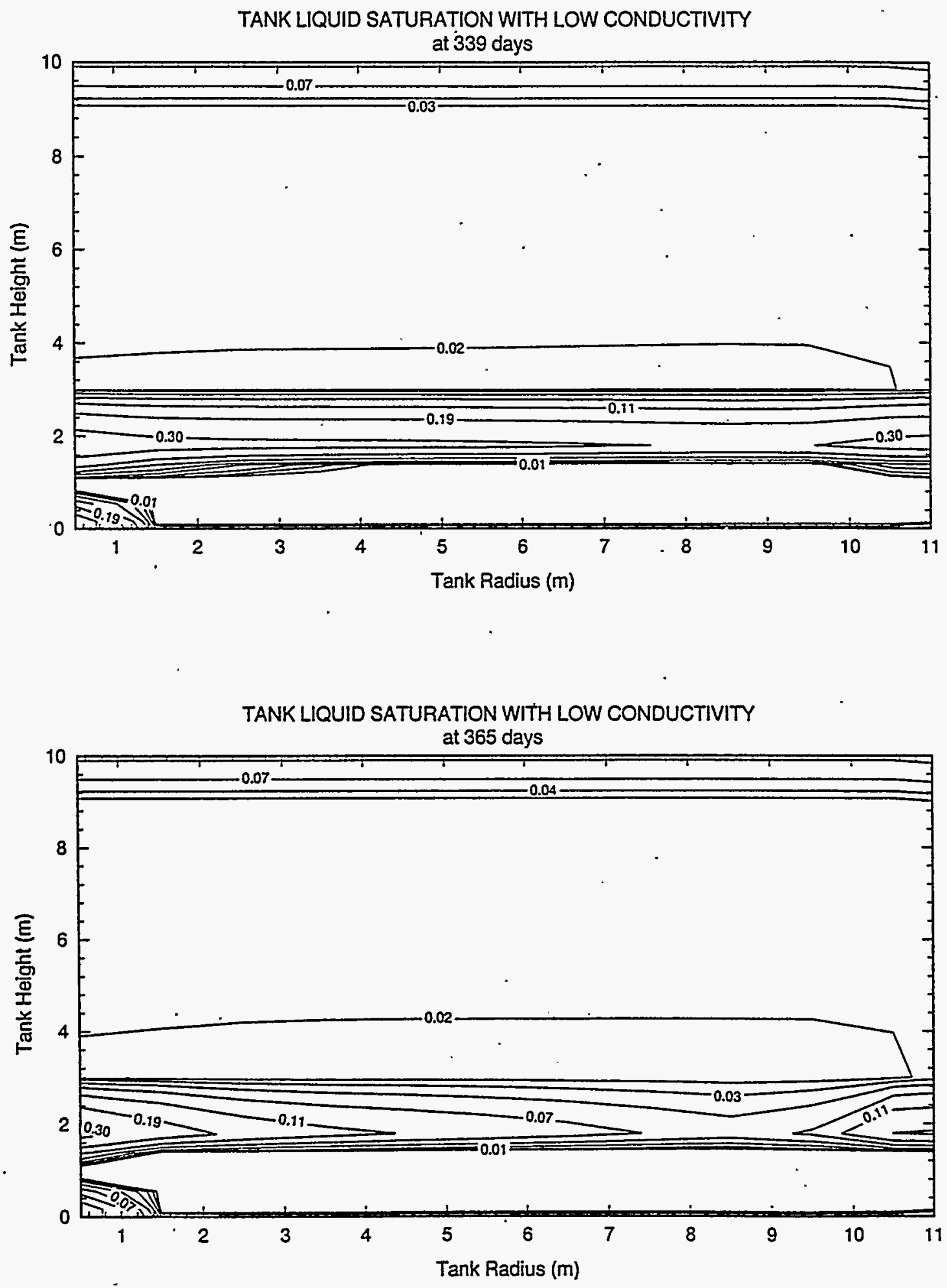

A-8 
WHC-EP-0831

APPENDIX B

HEAT-PIPE PROBLEM

FOR TOUGH2 BENCHMARK CASE

B-1 


\section{B. 1 Benchmark Case}

In order to ensure that the TOUGH2 code was working properly on the computers at Hanford, a benchmark test case was needed that exercised the critical features needed for the tank dryout problem. Fortunately, the TOUGH2 documentation included a heat-pipe problem with calculated results using the same TOUGH2 EOS4 module that was used for the analys is in this report. In this appendix, the heat-pipe problem is defined and the output results from the TOUGH2 documentation and from the Hanford computers are displayed for comparative purposes. The two outputs are essentially the same, indicating that the version of TOUGH2 on the Hanford computers is working correctly.

Heat pipes are systems in which an efficient heat transfer takes place by means of a liquid-vapor counterflow process, with vaporization and condensation occurring at the hot and cold ends, respectively. This is analogous to a tank dryout process with vaporization occurring in the hot sludge and condensation occurring on the tank top and below the large drainage hole.

The benchmark heat-pipe problem models a high-level nuclear waste emplacement in an approximate way. The problem consists of a cylindrical heater of $0.3-m$ radius and $4.5-\mathrm{m}$ height that provides a constant output of $3 \mathrm{~kW}$ into a porous medium with uniform initial conditions of 18 degrees Centigrade for temperature, 1 bar for gas pressure, and a $20 \%$ gas saturation. The onedimensional radial grid consists of 120 active elements extending to a radius of $10,000 \mathrm{~m}$ which is practically infinite for the time scales of interest here. This problem is representative of the thermal tank problem.

Most of the porous media parameters are identical to data used in previous modeling studies at Yucca Mountain (Pruess et a1., 1990), except that the low rock permeabilities (of order 1 micro-Darcy) are increased by a factor of 10,000 , to $20 \mathrm{milli-Darcy}$ in order to get more flow in the medium and to get a more interesting heat-pipe.

The reason for choosing a constant rate of heat generation is that this way the heat-pipe problem admits a semi-analytical solution (0'Sullivan, 1981; Doughty and Pruess, 1990). Comparison of the TOUGH2 heat-pipe solution with the semi-analytical solution affords a rather comprehensive code verification, as all of the non-linearities of two-phase flow behavior and of fluid and heat flow coupling are rigorously described by the semi-analytical solution.

The agreement between the Berkeley version of TOUGH2 and the semi-analytical solution is excellent (Pruess, 1991). Attachment 1 is the output from the Berkeley version of TOUGH2, and Attachment 2 is the output from the Hanfordimplemented TOUGH2 code. The agreement is excellent as only the very small numbers (around $10^{-28}$ ) differ by more than four significant digits. Hence, this shows that the Hanford-implemented version of TOUGH2 works correctly for the heat-pipe benchmark problem. 
WHC-EP-0831

ATTACHMENT B.2

Heat-Pipe Problem Output Generated by TOUGH2 at Hanford

*RHP* I-D RADIAL HEAT PIPE

OUTPUT DATA AFTER, 28, 31-2-TIME STEPS

THE TIME IS .36525E-03 EAYS

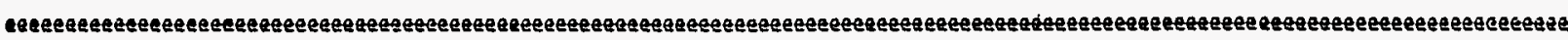

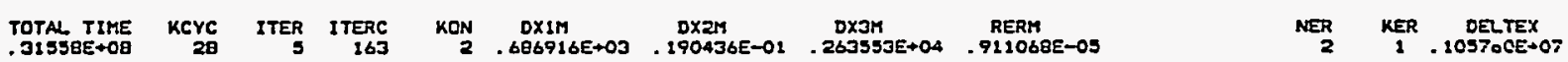

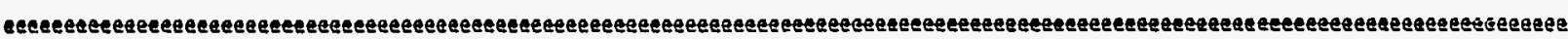
Elem. INOEX

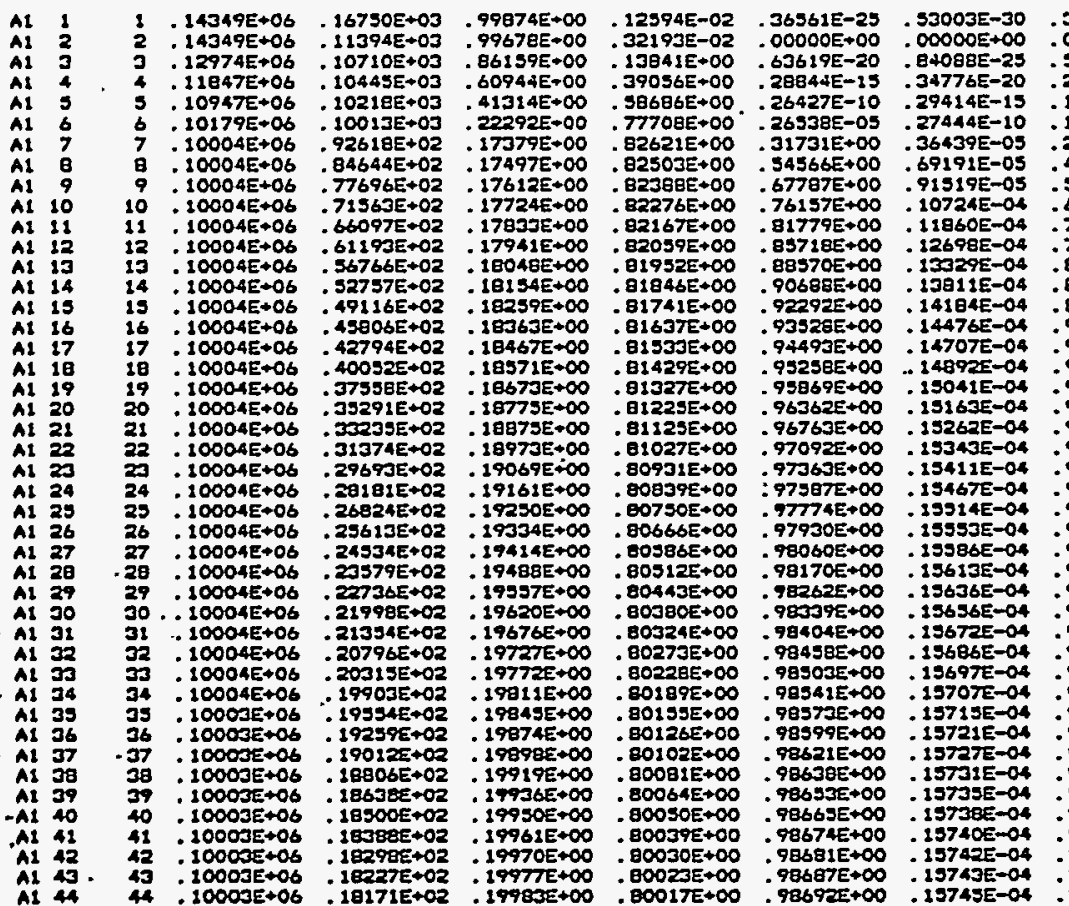

pair pop

$32973 E-20-301496-09$ $\rightarrow 09 \quad .71286 \mathrm{E}+00 \quad .80563 \mathrm{E}-03$ $21872 E+08$. $91859 E+00: .94-65 E+03$

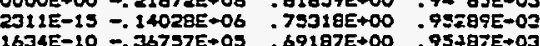

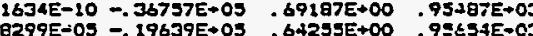

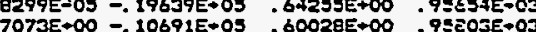

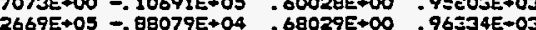
$3044 E+05=.80525 E+04 \quad .76792 E+\infty 0 \quad .96269 E-05$ $\$ 6934 E+05=.88937 E+04$. $83381 E+\infty \quad: 97 \geq 0 \% E=03$

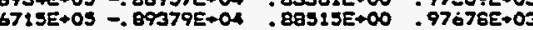
3782E+05 -. 89793E+04 .92630E-00 .977900E-03 $78997 E+05$-.90200E+04 .96008E+00 .99236E-0 .92921E+05 $-.90604 E+04 \quad .98940 E+00 \quad .98283 E+03$ 95917E+05 $-.91004 E+04 \quad .10125 E+01 \quad .98 E 78 E-03$

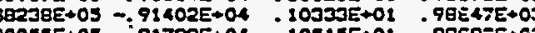
. $0053 E+05=91798 E+04 \quad .10515 E+01 \quad .9859 E E+03$ 11494E+05 =.92192E+04 .10674E+01 .99118E-03 . $10916 E+08$. $99227 E-03$ 94944E+05 $=.93739 \mathrm{E}+04.11133 \mathrm{0}+01.90472 \mathrm{O}+03$ $9542 E+05=.94112 E+04$. $11244 E+02.99533 E+03$ $95972 E+05=.94476 E+04 \quad$ : $11325 E+01 \quad .99595 E+03$ $06221 E+05-.94828 E+04: .11397 E+01$.99629E+03 .6511E+05 = 95166E+04:11461E+01 :99667E+03 9675SE+03 -. 95489E+04 :.11318E+01 :99700E+03 $969578+05=.95792 E+04, .21569 E+01.99728 E+03$ $97130 E+05-.96076 E+04.11614 E+01.99752 E-03$ M7274E+0S $-.96337 E+04.11693 E+01 \quad .997728-03$ $973958+03=.96577 E+04 \quad .11698 E+01.99789 E+00$ $97497 E+03 \quad-96794 E+04.11718 E+01 \quad .998038+03$ 97982E+05 $-.96987 E+04 \quad .11744 E+01 \quad .99516 E+03$ $97653 E+03=.97159 E+04.11766 E+02.99526 E+03$ . $11785 E+01 \quad-99634 E+03$ .77028 $=97405$ 97037000

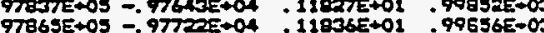
$97897 E+05$ - $97787 E+04: 11844 E+01 \quad 99656 E+03$ $97905 E+05=.97941 E+04$. $111051 E+01.99862 E+03$ $97920 E+09=97804 E+04.110562+01$.99864E+03 $97931 E+05=.97918 E+04.11860 E+01.99866 E+03$ $97940 E+05$
97947E+05 $=.97946 E+04$
:.11863E+01 1 


\section{WHC-EP-0831}

\section{B.2 References}

Doughty, C., and K. Pruess, 1990. "A Similarity Solution for Two-Phase Fluid and Heat Flow Near High-Level Nuclear Waste Packages Emplaced in Porous Media", International Journal of Heat and Mass Transfer, 33, (6), pp. 12051222.

0'Sullivan, M. J., 1981. "A Similarity Method for Geothermal We71 Test Analysis", Water Resources Research, 17, (2), pp. 390-398.

Pruess, K., J. S. Wang and Y. W. Tsang, 1990. "On Thermohydrological Conditions Near High-Level Nuclear Wastes Emplaced in Partially Saturated Fractured Tuff. Part 1: Simulation Studies with Explicit Consideration of Fracture Effects", Water Resources Research, 26, (6), pp. 1235-1248. 


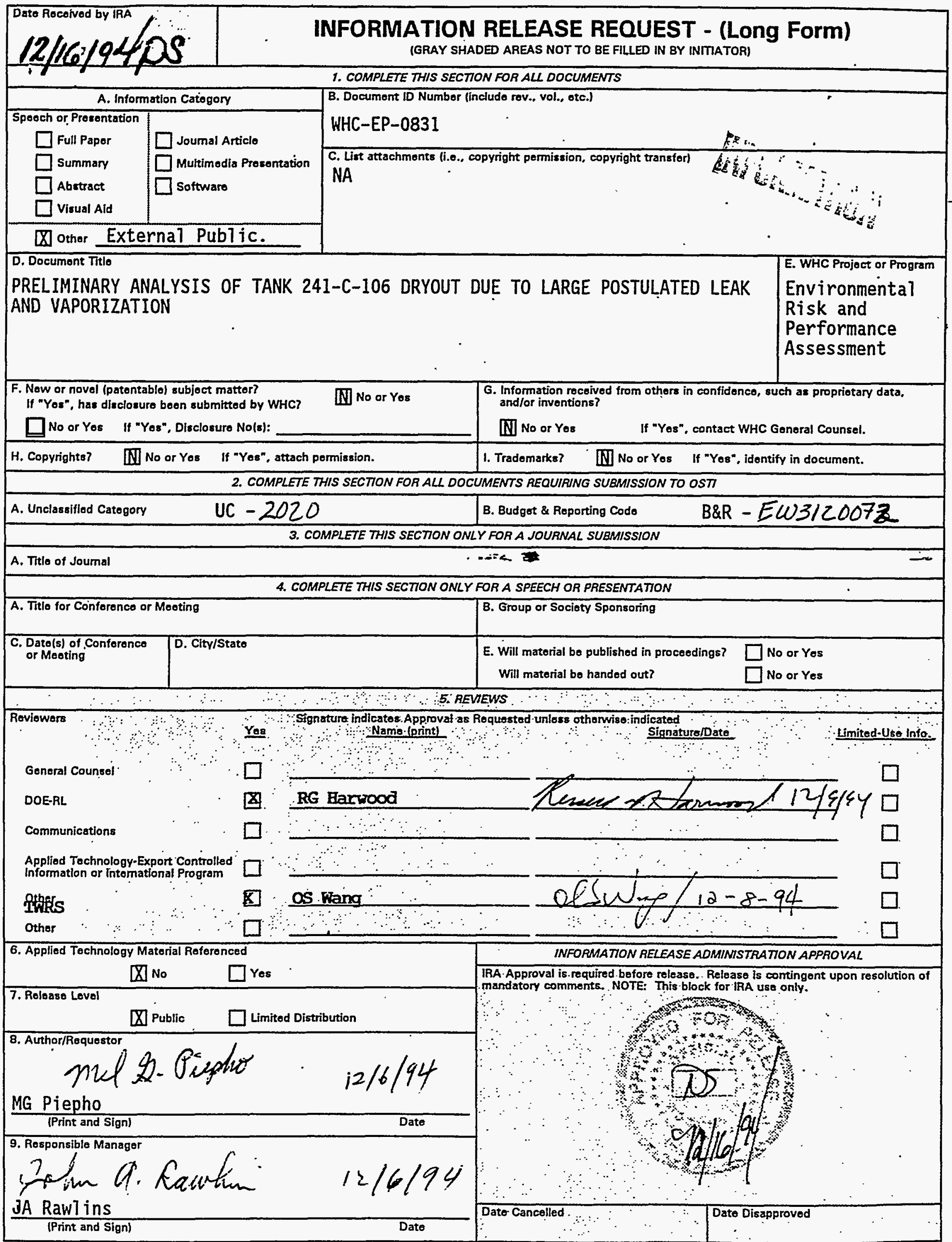


WHC-EP-0831

Document 10 Number

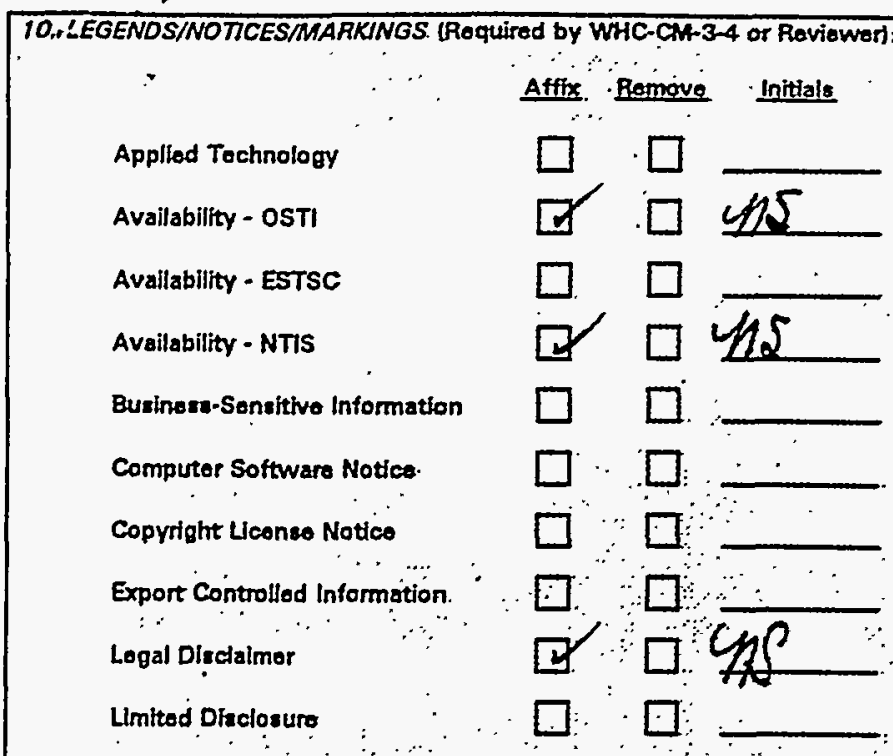

11. MANOATORY COMMENTS. IUST only mandatory comment hero All othor commonts shall be mads on the doctmont and rotumed to the author:?

Official Use Only

Potent Status

Prodecisional Information

Programmatic Notice

Propriatary Information

Purpose and Uso.

Thosia/Diseortation

Trodemark: Disclainer

Other:
Affix Bomove, fintials

$\square \square$

$\square \square$

口. $\square$

$\square \cdot \square$

$\square: \square$

$\square$

$\square$

$\square$

$\square$

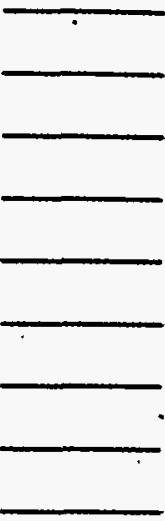

Roviowor (Print:\& Sign)

\begin{tabular}{|c|c|}
\hline Date & $\begin{array}{c}\text { Resolved by Author/Requestor } \\
\text { (Print \& Sign) }\end{array}$ \\
\hline & \\
\hline
\end{tabular}

Dato 


\section{RELEASE AUTHORIZATION}

Document Number: $\quad$ HHC-EP-0831

Document Title: Preliminary Analysis of Tank 241-C-106 Dryout Due to Large Postulated Leak and Vaporization

Release Date: $\quad 12 / 16 / 94$

\section{This document was reviewed following the procedures described in WHC-CM-3-4 and is:}

\section{APPROVED FOR PUBLIC RELEASE}

WHC Information Release Administration Specialist:

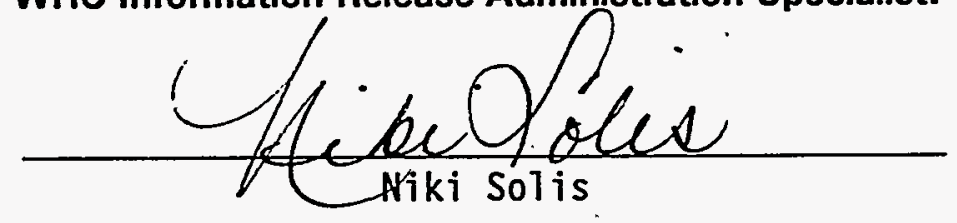

TRADEMARK DISCLAIMER. Reference herein to any specific comercial product, process, or service by trade name, trademark, manufacturer, or otherwise, does not necessarily constitute or imply its endorsement, recomendation, or favoring by the United States Government or any agency thereof or its contractors or subcontracţors.

This report has been reproduced from the best available copy. Available in paper copy and microfiche. Printed in the United States of America. Available to the U.S. Department of Energy and its contractors from:

U.S. Department of Energy

Office of Scientific and Technical Information (OSTI)

P.0. Box 62

Dak Ridge, TH 37831

Telephone: (615) 576-8401

Available to the public from:

U.S. Department of Commerce

National Technical Information Service (NTIS)

5285 Port Royal Road

Springfield, VA 22161

Telephone: (703) $487-4650$ 